\title{
Silvopastoral systems as a support for sustainable development in the southwestern region of the state of Rio Grande do Sul, Brazil
}

Sonia Aparecida Guetten Ribaski guetten@uol.com.br BRFOR Soluções Florestais LTDA, Itapeva, São Paulo, Brasil

Vitor A. Hoefich

vitor.ufpr@gmail.com

Paraná, Curitiba, Paraná, Brasil

\section{Jorge Ribaski}

ribaski@cnpf.embrapa,br

Embrapa Florestas, Colombo, Paraná, Brasil

Nayara Guetten Ribaski nayribaski@hotmail.com

Pontifícia Universiade Católica do Paraná, Curitiba, Paraná, Brasil

\begin{abstract}
An economic viability analysis was performed for different eucalypt wood production systems (Eucalyptus grandisHill ex. Maiden) in two rural properties located in Alegrete municipality, RS. The traditional pasture system was compared with two other alternative systems, one of them represented by a pasture land converted to homogeneous eucalypt plantation by using two plant densities (2,222 and 1,111 trees.ha-1) and the other represented by a silvopastoral system with 1000 and 500 trees.ha-1. The results were analyzed by determining the Internal Return Rate (IRR) and comparing to the Minimum Attractive Rate (MAR). The alternatives with and without land value were evaluated taking into account the wood price variation (increase and reduction of $5 \%$ ) and the wood volume (increase and reduction of $10 \%$ ). Considering land value, all the alternatives showed IRR lower than MAR (3.72\%). The sensibility analysis showed that when price and volume yield of wood increased, most of the alternatives which use thinning presented IRR higher than MAR, except the silvopastoral system at plantation density of 500 trees.ha-1. In conclusion, the implementation of the forest component is economically viable when land value is not considered.
\end{abstract}

PALAVRAS-CHAVE:Extensive cattle raising; forestry production; agroforestry system; economic evaluation; Eucalyptus grandis. 


\section{INTRODUCTION}

The discussion on sustainable development in the mid-southern Rio Grande do Sul, particularly in the Pampa Biome, is the subject of several studies regarding the model of development in the region and its effects on population and environment. There is a consensus in these studies on the need of diversify the production systems to improve profitability.

The livestock production chain is one of the most traditional in the state, with great economic and social relevance, and influences regional integration. Nevertheless, the economic return of beef livestock has been reduced by the increase in input prices, besides the reduction in the live cattle value paid to producers. Considerable part of beef cattle farms depends exclusively on natural forage resources for feeding cattle, which are extensively used resulting in low production per unit area, what frequently can make infeasible small and medium farms (Costa et al., 2006; Aguinaga, 2009; Silva and Alves, 2009; Ruviaro et al, 2016).

The southwest region of the state is considered an area of high socioeconomic vulnerability due to the presence of extensive sand formations which have been undergoing changes in vegetations patterns caused by the decrease in vegetation cover and, consequently, increasing soil erosion, resulting in degradation of the regional ecosystem, named Pampa Biome. This process of environmental degradation has negatively affected the socioeconomic conditions, causing a reduction in the quality of life of the countrymen. Currently, there is a tendency for significant changes in the different systems of land use, and aspects relative to environmental sustainability and creation of new socioeconomic alternatives are becoming progressively more important for the producers of this region (Ribaski et al., 2005; Ribeiro and Verdum, 2013).

Since the year 2000, new and important investments are made in the midsouth region by cellulose and paper industries. These investments include also structuring a forestry sector integrated on productive chains, involving several cities of the region. Thus, outlines a scenario for the mid-south region, with an economic structure more diversified and dynamic, with expansion of grain crop integrated to a more productive beef livestock, on lands with greater potential use, and the establishment of a stronger forestry sector associated with agroindustrial chains in areas with low agricultural suitability (Ilha et al., 2006; Castilhos et al., 2009).

Silvopastoral systems (SPSs) are an important strategy for the sustainable use of land, especially in areas subjected to environmental degradation, and also a new source of economic value aggregation to rural property through wood exploitation (Ribaski et al., 2005; Varella et al., 2016). Several researches show advantage of SPSs compared to traditional systems, particularly for meeting the assumptions of economic and social development related to protection and increase in environmental sustainability of the productive systems (Rakocevic and Ribaski, 2003; Ribaski, 2008; Ribaski, 2017). On the other hand, these systems are more complex than the traditional, requiring detailed technical information about every one of the components for the definition of an appropriate strategic planning in order to achieve the desired success.

In this context, it is necessary to expand the scientific basis to provide 
technical information, mainly to determine the technical viability of these systems. In the studied region, the use of SPSs is still incipient and few researches include evaluations of these integrated production systems. From this perspective, the present study was done aiming to evaluate the economic impact of the use of SPSs to assist the rural development of the southwest region of Rio Grande do Sul.

\section{MATERIAL AND METHODS}

\section{Characterization of the Standard Unit}

The production unit known as "Model Farm" was conceived from data obtained in a research carried out in the region studied by EmbrapaFlorestas, togheter with EmbrapaClimaTemperado, EmbrapaPecuária Sul and other research, teaching and extension institutions. The project was implemented in 2002 in Alegrete/RS in two farms previously selected by the partner institutions, based on socioeconomic and edaphic conditions representative of the region.

The Model Farm was $300 \mathrm{ha}$, the size limit for considering the area as a family farming, which represents most of the beef cattle producers (Pillar et al., 2006; Nabinger et al., 2009). The effective area for productive use was 175 ha, after disregard the areas of restricted production such as Permanent Preservation Areas and Legal Reserves, and area employed with infrastructure of the property - farmhouse, shed, corral and other improvements.

\section{Detailing of the alternatives for comparative economic analysis.}

Five alternatives were outlined combining the forms of land use in the standard unit - the Model Farm - in order to analyze the economic viability of livestock and homogeneous forest plantations and SPSs with Eucalyptus grandis (Table 1).

TABLE 1 - Row spacing and planting density of Eucalyptus grandis for the alternatives evaluated.

\begin{tabular}{cccc}
\hline Alternative & \multicolumn{1}{c}{ Treatment } & Rowspacing & InitialDensity \\
\hline 1 & Extensivecattleraising & ---- & --- \\
2 & Homogeneous plantation & $3 \mathrm{~m} \times 1.5 \mathrm{~m}$ & $222 \mathrm{trees} / \mathrm{ha}$ \\
3 & Homogeneous plantation & $3 \mathrm{~m} \times 3 \mathrm{~m}$ & 1111 trees/ha \\
4 & Silvopastoral system 1 & $(3 \mathrm{~m} \times 1.5 \mathrm{~m}) \times 14 \mathrm{~m}$ & 1000 trees/ha \\
5 & Silvopastoral system 2 & $(3 \mathrm{~m} \times 1.5 \mathrm{~m}) \times 34 \mathrm{~m}$ & 500 trees/ha \\
\hline
\end{tabular}




\section{Alternative 1: tradicional cattle raising}

Refers to the use of the traditional system of extensive beef cattle raising in the production area, to growing and finishing steers, which requires on average two hectares per head (Miguel et al., 2007).

The average weight for purchase one-year-old steer and sale three-year-old animals was $230 \mathrm{Kg}$ and $350 \mathrm{Kg}$, respectively. For calculation purposes, the average productivity considered was approximately $60 \mathrm{Kg}$ body weight.ha-1.year-1 (Pillar et al., 2006; Carvalho et al., 2006) and value of purchase and sale of cattle $\mathrm{R} \$ 2.00 / \mathrm{kg}$.

In the first year of the research, three-year-old cattle were commercialized and 45 new one-year-old heads were acquired. Thus, the producer maintained the cattle herd stable, with the maximum number of 90 heads, as proposed for extensive cattle raising on native pasture, commercializing 45 heads annually.

\section{Alternatives 2 and 3: Livestock with gradual conversion to homogeneous forest plantation}

These alternatives comprised a gradual conversion of the pasture area to eucalyptus plantation using densities of 2222 and 1111 trees.ha-1, respectively. The production area (175 ha) was divided in seven modules of $25 \mathrm{ha}$, and one module was annually converted so that in the seventh year the total production area was converted. Consequently, the number of cattle heads was gradually reduced, replaced by forestry plantation (Figure 1).

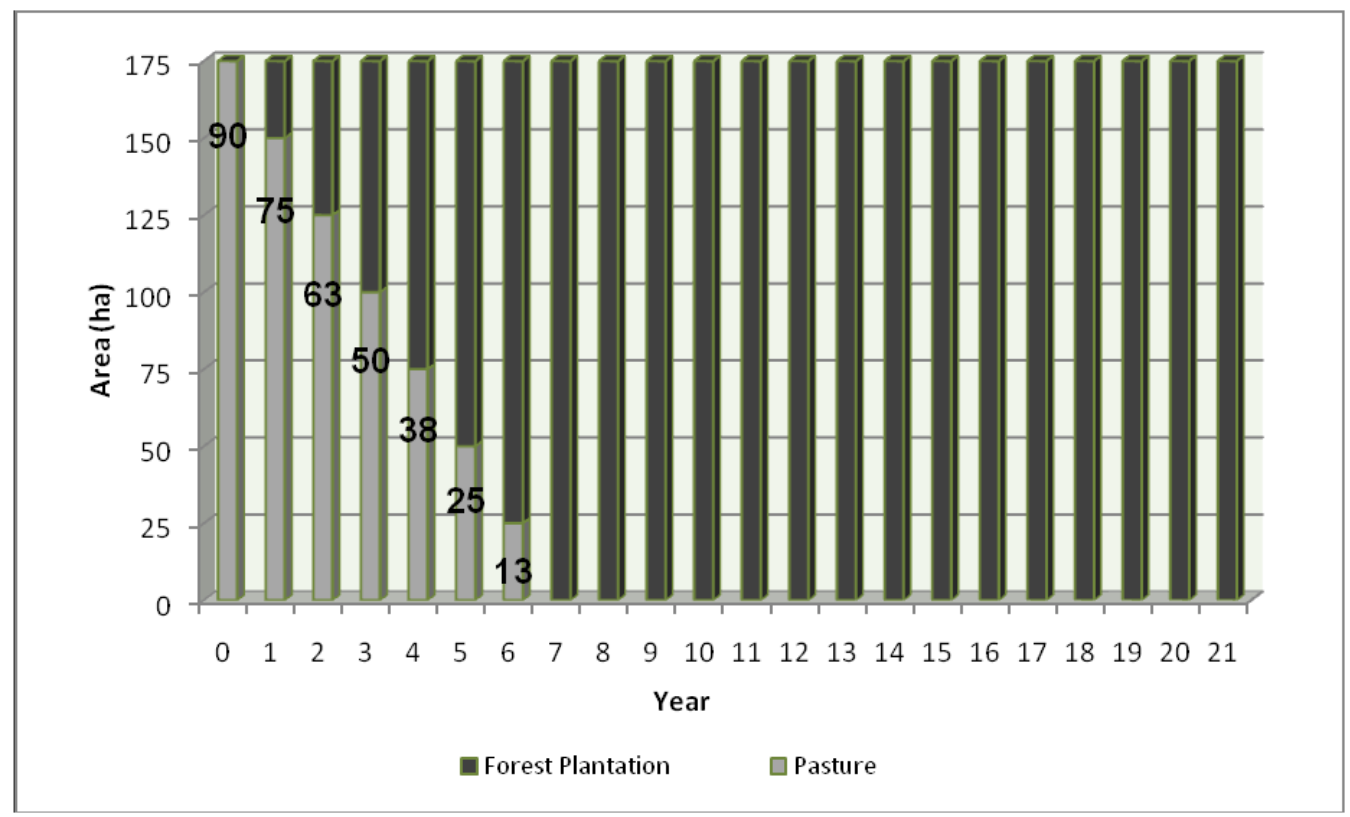

FIGURE 1 - Annual distribution of the gradual conversion of extensive livestock to homogeneous forest plantation and respective number of heads of cattle. 


\section{Alternative 4: Silvopastoral system with 1000 trees.ha-1}

This alternative represents the use of SPS with triple row eucalyptus, with 3 $\mathrm{m} \times 1.5 \mathrm{~m}$ row spacing, totaling 1000trees.ha- 1 , and a $14 \mathrm{~m}$ corridor of native pasture between the sets of lines, resulting in $45 \%$ of the area for forest plantation and $55 \%$ for pasture (Figure 2). Therefore, in the 25 ha module, 11.5 ha are designed for forest production and 13.75 ha for extensive cattle ranching.

Thus, this system predicts the gradual introduction of forest plantation through seven years and, conversely, reduction of pasturing. Therefore, cattle is the activity that originally occupies most of the land ( 90 heads), being gradually reduced to 49 heads, corresponding to final land occupation of 55\%, i.e., 96 ha of pasture. 


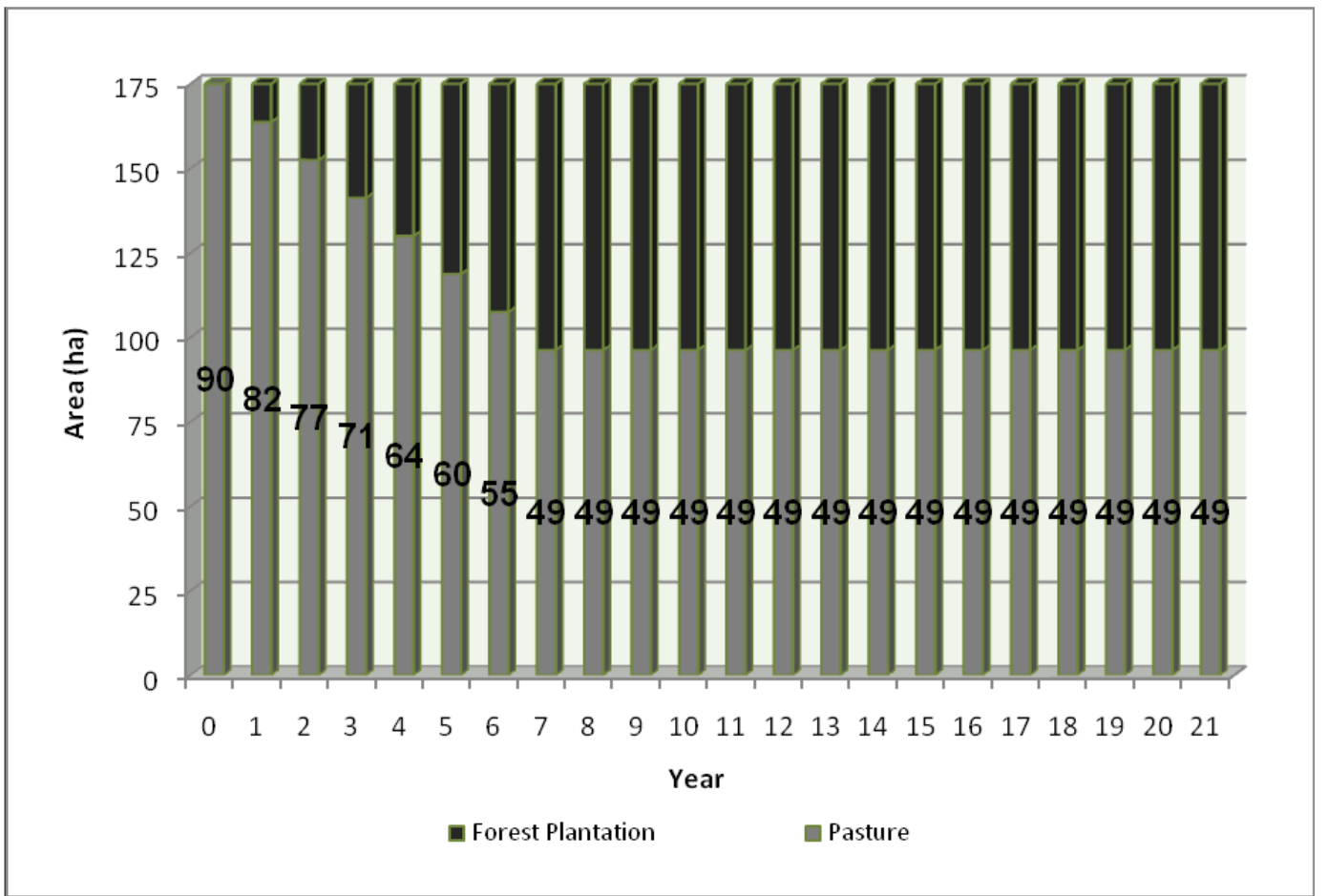

FIGURE 2 - Annual distribution of the gradual conversion of extensive livestock to silvopastoral system with 1000 trees/ha and number of heads of cattle per year.

\section{Alternative 5: Silvopastoral system with 500trees.ha-1}

Consists in the utilization of SPS with triple row eucalyptus, with $3 \mathrm{~m} \times 1.5 \mathrm{~m}$ row spacing, totaling 500trees.ha-1, and a $34 \mathrm{~m}$ corridor of native pasture between the sets of lines, which corresponds to $22.5 \%$ for forest plantation and $77.5 \%$ for pasture. Therefore, in the 25 ha module, 5.6 ha are designed for forest production and 19.4 ha for extensive cattle ranching, corresponding to 70 heads for final occupation of 135 ha of pasture (Figure 3). 


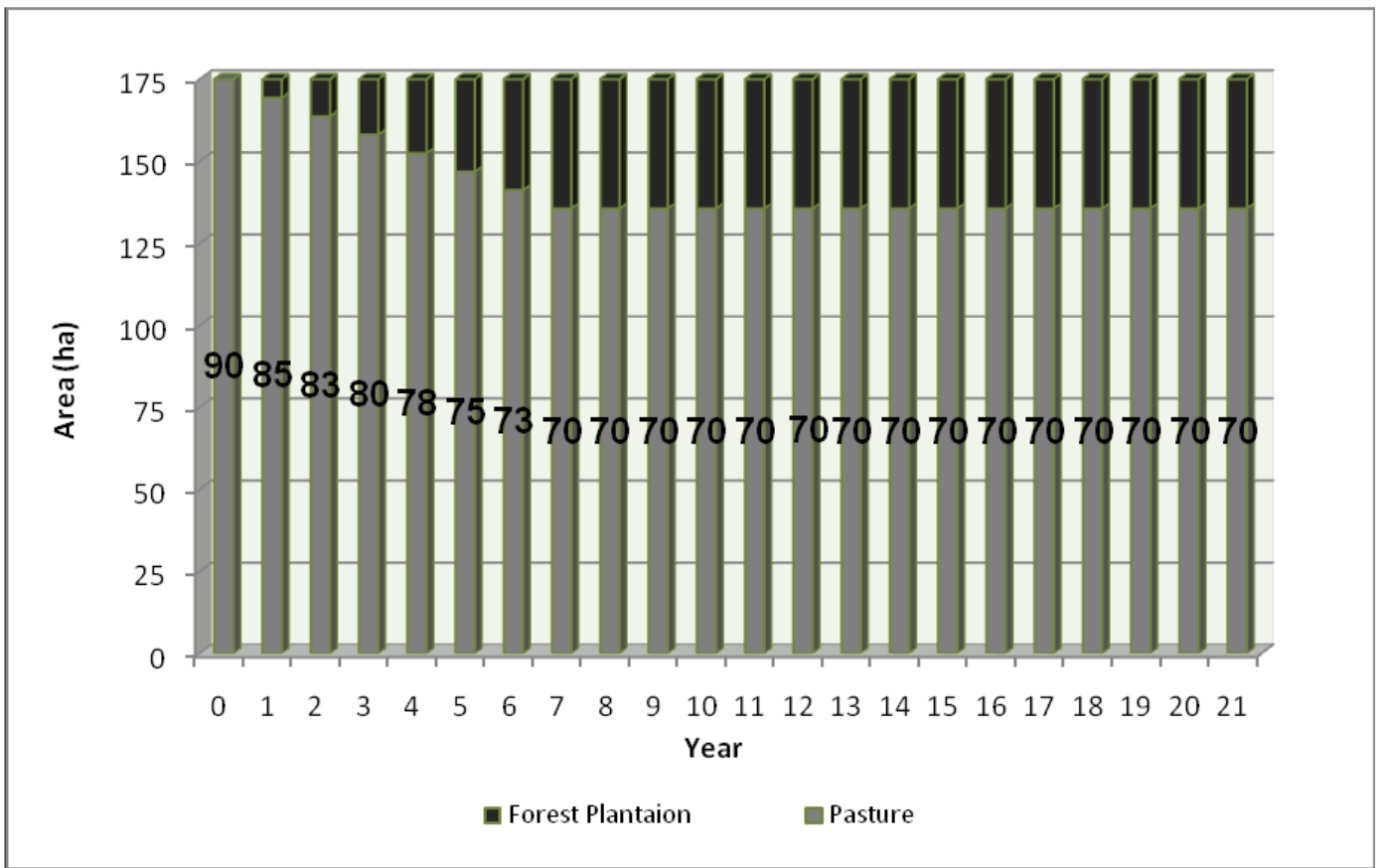

FIGURE 3 - Annual distribution of the gradual conversion of extensive livestock to silvopastoral system with 500 trees/ha and number of heads of cattle per year.

\section{Forestry Production}

The production cycle defined in this study comprised 21 years, with the first cut at seventh year, and simple coppice management system until 14 years (Stape, 1997; Rodriguez, 1999), when the second cut occurred. Each year a new 25 ha planting was performed during a period of seven years. From the seventh year, a clearcutting was done in each module and regrowth was conducted until the second cut. The last planting was carried out at seventh year and regrowth was conducted and cut at 21 years, ending the cycle.

Aiming to increase the percentage of wood for sawmill (greater aggregate value), in addition to the system previously described, a differentiated management was also adopted, consisting of selective thinning of $70 \%$ of the trees at seven years, maintaining the $30 \%$ of the remaining trees presenting better quality to be cut at 14 years, together with the cutting of second rotation.

The estimated wood production for SPSs and homogeneous plantations until the end of the cycle was simulated by the SisEucalipto software (Oliveira et al., 2006; Oliveira, 2011), expressed in m3.ha-1. In the present study, the decrease in volume established for the prognosis of the second rotation was 25\% (Berger, 1979; Silva, 2013). The value of standing timber for sale for cellulose production was $R \$ 20.00 / m 3$ and for sawmills $R \$ 50.00 / m 3$. Raw material for cellulose comprised the energy assortment (SisEucalipto) and for sawmill wood the sum of assortments of lamination and sawmill was considered. 


\section{Criteria for economic evaluation}

Economic analysis was based essentially on the comparison of production activities of the alternative arrangements. This comparison was done by criteria that consider the update on capital variation according to the distribution throughout 21 years.

Investments in farm, costs of implementation and maintenance of eucalyptus, costs of inputs, manpower and maintenance of cattle in the different alternative systems were included in cash flow. Also were included the revenues resulting from the commercialization of products obtained during the entire cycle, i.e., sale of cattle and wood.

For the analysis of viability of the arrangements, a minimum attractive rate (MAR) was considered equivalent to the real income of savings (nominal saving minus inflation). For the period 1996-2006, the average nominal saving was $10.57 \%$ and average inflation expressed by INPC (national consumer price index) was $6.85 \%$, resulting in a real saving of $3.72 \%$, applied as MAR for evaluation of the alternatives.

The closer internal rate of return (IRR) and MAR, the greater risk of the project (even with superior IRR). If IRR is inferior to discount rate, the yield of the project will be lower than if invested in another project applied to the discount rate. In other words, must be preferred the investment presenting the highest IRR.

\section{Sensitivity analysis}

A sensitivity analysis of IRR to variations in the productivity indexes and wood prices was performed, to establish the influence of these factors on the economic viability of the alternatives. For sensitivity analysis, the variation of increase and decrease of $5 \%$ in wood price (cellulose and sawmill) and increase and decrease of $10 \%$ in timber productivity was simulated.

Considering that producer already own the land, which would mean only the conversion of extensive livestock in homogeneous forestry plantation or SPS, analysis were also performed excluding the values of land acquisition. However, for every alternative all costs and investments required by forestry and livestock were taken into account.

\section{RESULTS AND DISCUSSION}

\section{Eucalyptus growth estimation in the different alternatives examined}

The use of thinning in all the alternatives promotes a greater increase in total productivity. This increase is expected since the thinning of $70 \%$ of the trees in the seventh year promotes the opening of the stand, thereby reducing the competition for light, water and nutrients by the remaining trees. The suitable for use in sawmill, resulting in a higher value of the row material 
produced.

Productivity in the different alternatives for the production period of 14 years, corresponding to two cycles, is presented in Figure 4.

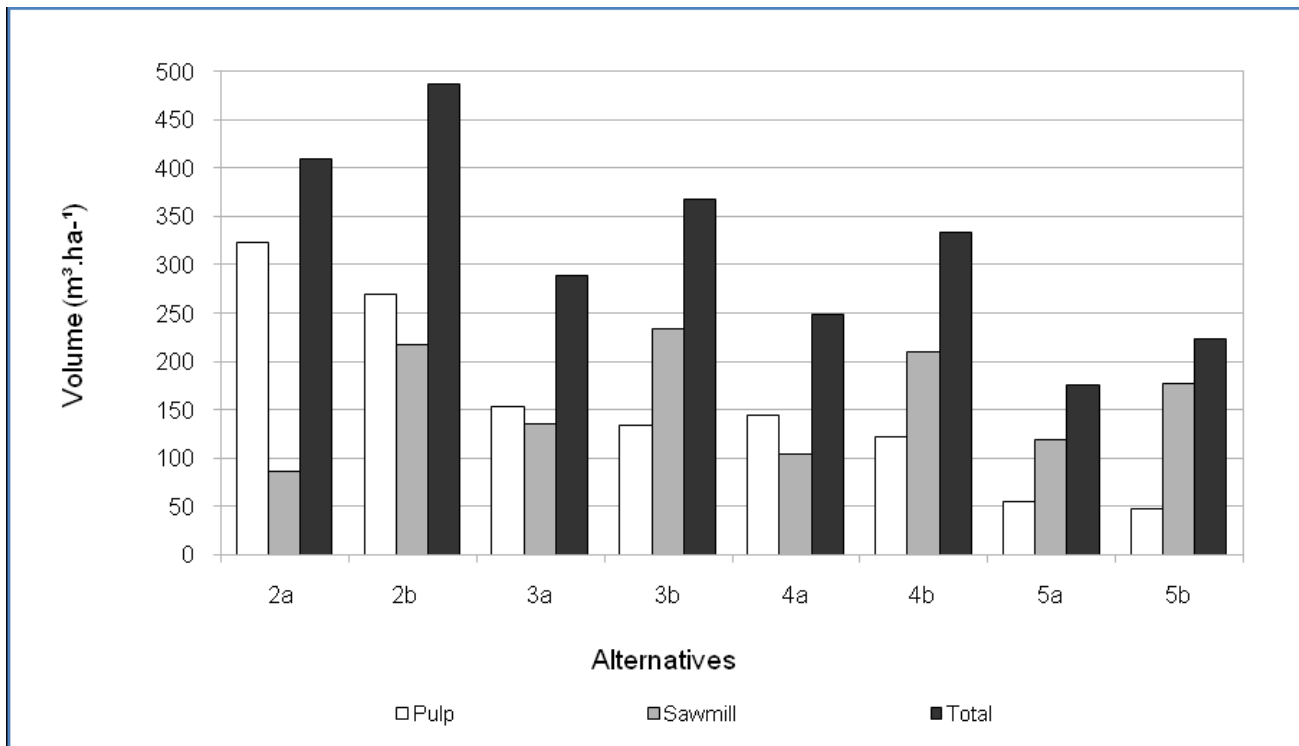

FIGURE 4 - Total production of wood for cellulose and sawmill in the different alternatives, with and without thinning, in a 14 years cycle. Notes: a -indicates management without thinning; $b$-indicates management with selective thinning of $70 \%$ of the trees in the seventh year.

Regarding total productivity, greater volume of wood was observed in the alternatives where thinning was accomplished. The adoption of management by thinning promoted, in all alternatives, a greater increase in total productivity, with $18.6 \%, 27.26 \%, 33.96 \%$ and $27.84 \%$ for the alternatives $2,3,4$ and 5 , respectively. This increase was more evident when considered the sum of sawmill and lamination, with an average increase of $93.5 \%$.

\section{Comparative analysis of the alternatives}

Table 2 shows the results of IRR calculations, obtained from the different alternatives tested, extracted from the cash flows, over the entire period of 21 years, considering all the investments, including land value.

A project is economically viable if present IRR > MAR. From data of Table 2 one can verify that, for MAR of $3.72 \%$ per year, as homogeneous plantations as SPSs considering land value present IRR below MAR, being MAR defined as average value of real savings after discounted the inflation (considered the historical series from 1996 to 2006). 
TABLE 2 - Comparison of the Internal Return Rate (IRR) obtained in the economic analysis of the evaluated alternatives, with and without thinning.

\begin{tabular}{l|c|c}
\hline \multicolumn{1}{c|}{ Alternative } & $\begin{array}{c}\text { IRR (\%) } \\
\text { Withoutthinning }\end{array}$ & $\begin{array}{c}\text { IRR (\%) } \\
\text { Withthinning }\end{array}$ \\
\hline $\begin{array}{l}\text { Alternative 1: } \\
\text { traditionalextensivelivestock }\end{array}$ & $<0$ & $<0$ \\
\hline $\begin{array}{l}\text { Alternative 2: homogeneous } \\
\text { plantation - 3m x 1.5m - 2222 } \\
\text { trees/ha }\end{array}$ & 1.04 & 3.12 \\
\hline $\begin{array}{l}\text { Alternative 3: homogeneous } \\
\text { plantation - 3m x 1.5m - 1111 } \\
\text { trees/ha }\end{array}$ & 1.33 & 2.68 \\
\hline $\begin{array}{l}\text { Alternative 4: silvopastoral } \\
\text { system - 1000 trees/ha }\end{array}$ & $<0$ & 2.08 \\
\hline $\begin{array}{l}\text { Alternative 5: silvopastoral } \\
\text { system - 500 trees/ha }\end{array}$ & $<0$ & 0,62 \\
\hline
\end{tabular}

Regarding extensive livestock (alternative 1), releases show a negative net revenue. In this context, IRR could not be determined. The analysis of this study indicates that extensive livestock farming does not provide economic return to the producer. Total revenue for this alternative is insufficient to cover production costs.

The traditional use of land with extensive cattle production in natural grasslands (alternative 1) presented negative net revenue in the entire period evaluated, demonstrating to be economically infeasible. Although cattle were annually commercialized, the costs of production and maintenance of infrastructure exceeded the revenues.

Although the other alternatives have shown positive IRR, all rates were inferior to MAR, demonstrating the unviability of the investment in the considered conditions. In the evaluated conditions, the homogeneous forestry plantation with thinning is the economic alternative closer to the MAR to improve income, but still inferior. Forest planting requires relatively high initial investments that are compensated by productivity and final price of wood. This is a medium to long-term investment, with guaranteed return by the increasing forest market in Brazil and enhanced use of wood. However, the investments in land and improvements and financial losses caused by livestock contributed to the negative result in the initial years and also to the negative final results of some of the evaluated alternatives.

\section{Sensitivity Analysis}

The results of sensitivity analysis for the alternatives and scenarios evaluated are described in Table 3, considering variation of $5 \%$ in the wood price (cellulose and sawmill) and $10 \%$ in wood productivity, analyzing the alternatives with and without the value of land acquisition. 


\section{Analysis of the traditional extensive livestock model}

The alternative 1 did not present alteration of IRR (Table 3 ) because the gradual conversion to forest plantation or silvopastoral system was not involved. Thus, the extensive livestock farming practiced in natural grasslands in southwestern Rio Grande do Sul is economically unprofitable for the farmer, under the studied conditions. Similar results were also find in the diagnosis of beef cattle production systems in the State of Rio Grande do Sul (Carvalho et al., 2006; Miguel et al., 2007) indicating that agroeconomic results present low or negative economic efficiency indicators in most cases. According to this same diagnosis, $26.5 \%$ of producers practice the activity by tradition, $25.4 \%$ by satisfaction and $14.4 \%$ for considering a secure activity. Only $8.7 \%$ have a business view of the activity, aiming to obtain profit. In addition, cattle farmers have low technical qualification and little capital immobilized, being indebted and with difficulties in succession and continuity of cattle ranching.

Nevertheless, several researches show that the low performance of animals obtained on native field (60 kg live weight.ha-1.year-1) can be improved with simple procedures that does not cause substantial increase in the production costs (Pillar et al., 2006; Carvalho et al., 2006; Castilhos et al., 2009; Nabinger et al., 2009; Ruviaro et al, 2016). 
TABLE 3 - Sensitivity analysis for the alternatives evaluated with and without thinning and with or without land price and also considering changes in price and productivity of timber.

\begin{tabular}{|c|c|c|c|c|c|}
\hline \multicolumn{3}{|r|}{ ALTERNATIVES } & \multirow{2}{*}{$\begin{array}{l}\text { IRR } \\
(\%)^{*}\end{array}$} & \multicolumn{2}{|c|}{ SENSITIVITY ANALYSIS } \\
\hline & & & & $\begin{array}{c}\text { REDUCTION } \\
(\%)^{* *}\end{array}$ & $\begin{array}{c}\text { INCREASE } \\
(\%)^{* * * *}\end{array}$ \\
\hline \multirow{10}{*}{ 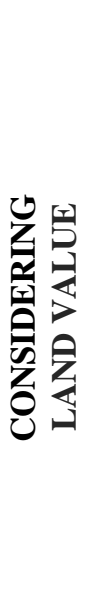 } & \multirow{5}{*}{ 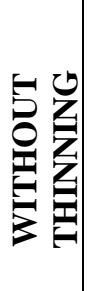 } & 1 - Traditionalextensivelivestock & $<0$ & $<0$ & $<0$ \\
\hline & & 2 - Homogeneous Plantation $3 \mathrm{~m} \times 1.5 \mathrm{~m}$ & 1,04 & 0,20 & 1,90 \\
\hline & & 3 - Homogeneous Plantation $3 \mathrm{~m} \times 3 \mathrm{~m}$ & 1,33 & 0,53 & 2,14 \\
\hline & & 4 - Silvopastoral System (1000 trees/ha) & $<0$ & $<0$ & 0,53 \\
\hline & & 5 - Silvopastoral System (500 trees/ha) & $<0$ & $<0$ & 0,29 \\
\hline & \multirow{5}{*}{ 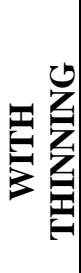 } & 1 - Traditionalextensivelivestock & $<0$ & $<0$ & $<0$ \\
\hline & & 2 - Homogeneous Plantation $3 \mathrm{~m} \times 1.5 \mathrm{~m}$ & 3,12 & 2,22 & 3,98 \\
\hline & & 3 - Homogeneous Plantation $3 \mathrm{~m} \times 3 \mathrm{~m}$ & 2,68 & 1,85 & 3,49 \\
\hline & & 4 - Silvopastoral System (1000 trees/ha) & 2,08 & 1,27 & 2,89 \\
\hline & & 5 - Silvopastoral System (500 trees/ha) & 0,62 & $<0$ & 1,29 \\
\hline \multirow{10}{*}{ 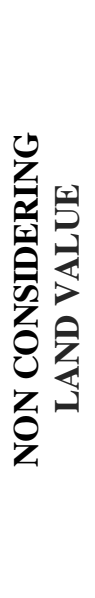 } & \multirow{5}{*}{ 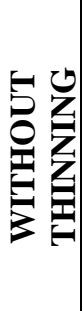 } & 1 - Traditionalextensivelivestock & $<0$ & $<0$ & $<0$ \\
\hline & & 2 - Homogeneous Plantation $3 \mathrm{~m} \times 1.5 \mathrm{~m}$ & 3,09 & 0,62 & 5,36 \\
\hline & & 3 - Homogeneous Plantation $3 \mathrm{~m} \times 3 \mathrm{~m}$ & 4,34 & 1,83 & 6,62 \\
\hline & & 4 - Silvopastoral System (1000 trees/ha) & $<0$ & $<0$ & 1,76 \\
\hline & & 5 - Silvopastoral System (500 trees/ha) & $<0$ & $<0$ & 1,03 \\
\hline & \multirow{5}{*}{$\frac{\Xi}{\mathrm{Z}}$} & 1 - Traditionalextensivelivestock & $<0$ & $<0$ & $<0$ \\
\hline & & 2 - Homogeneous Plantation $3 \mathrm{~m} \times 1.5 \mathrm{~m}$ & 6,69 & 4,97 & 8,28 \\
\hline & & 3 - Homogeneous Plantation $3 \mathrm{~m} \times 3 \mathrm{~m}$ & 6,53 & 4,71 & 8,19 \\
\hline & & 4 - Silvopastoral System (1000 trees/ha) & 4,92 & 3,14 & 6,55 \\
\hline & & 5 - Silvopastoral System (500 trees/ha) & 1,71 & $<0$ & 3,40 \\
\hline
\end{tabular}

Pillar et al. (2006), working with growing and finishing cattle systems, verified that only with the correct adjustment of stocking rate (almost zero cost) significant live weight gains can be achieved, in the order of $230 \mathrm{~kg}$.ha-1.year-1. Nabinger et al. (2009) reports that adjusting the stocking rate to the forage carrying capacity the values can reach between 150 and $170 \mathrm{Kg}$ live weight.ha1.year-1 with a fixed supply of forage throughout the year, and values close to 250 $\mathrm{kg}$. ha-1.year-1 alternating forage supply in the spring.

Deferral of native pasture, i.e., removal of animals from paddock for a period of time, is a cheap management tool that provides reserve of forage to be used during critical periods of the year (Castilhos et al., 2009, Nabinger et al., 2009). As emphasized by Carvalho et al. (2006) and Aguinaga (2009), the activity of beef 
cattle with the current characteristics of the production systems, probably does not meet the concepts of sustainability. Large part of properties depends exclusively on natural forage resources and uses it extensively, which causes low production per unit area, making unfeasible medium and small properties. This extensive production system does not provides substantial income to the producer, does not increment trade in the cities and does not contribute to the increase in availability of jobs in the region.

Analysis of alternatives with the forestry component, considering land value, with and without thinning

Increase in IRR percentage was observed for alternatives that computed $5 \%$ of increase in wood price and $10 \%$ of increase in productivity, for alternatives using thinning (Table 3). However, in general these increases were not enough to overcome MAR. Nevertheless, the alternative 2 presented IRR $3.98 \%$, superior to MAR.

IRR was inferior to MAR in the alternatives with reduction of $5 \%$ in wood price and $10 \%$ in productivity. Nonetheless, one can observe that with exception of the alternative 5 , all alternatives with thinning presented positive IRR, being superior to the alternatives without thinning.

Analysis of alternatives with the forestry component, not considering land value, with and without thinning

Considering $5 \%$ increase in wood price and $10 \%$ in productivity for alternatives with thinning, all IRR were positive. Alternatives 2, 3 and 4 were superior to MAR. Thus, the producer can choose homogeneous plantations or SPSs with 1000 tres.ha-1 (alternative 4). For the alternatives without thinning, 2 and 3 presented IRR above MAR (homogeneous forestry plantations), and alternatives 4 and 5 did not present the expected result.

Analyzing the alternatives with $5 \%$ of reducing in wood price and $10 \%$ in productivity, with thinning, only alternatives 2 and 3 (homogeneous forestry plantations) presented IRR superior than MAR, even with decrease in price and volume of wood, while all the alternatives without thinning presented IRR below MAR. In general, the alternatives of wood commercialization, prioritizing raw material for sawmill, using thinning, presented IRRs higher than those managed by simple coppice, being more profitable. Similar results were observed by Pavan et al. (2010) in Rio Grande do Sul, where the authors verified that producing eucalyptus wood for energy does not bring viability higher than the opportunity cost. Already producing wood from eucalyptus for sawing has proved to be a viable economic option.

\section{FINAL CONSIDERATIONS}

The traditional extensive cattle raising is economically unviable, despite annual cattle commercialization. For this model, costs of production and maintenance of infrastructure overcome revenues. Silvopastoral systems and 
homogeneous forest plantations do not present profitability superior than MAR, when computed all the investments.

When the value of land acquisition was not considered, the alternatives using thinning presented IRR higher than MAR, except the alternative involving SPS with 500trees.ha-1, which showed no economic viability in the analysis.

Silvopastoral systems and homogeneous plantations are more likely to increase income than the traditional extensive cattle ranching of the region and, consequently, show greater tendency to socioeconomic sustainability.

The silvopastoral activity provides subsides for diversifying the income of the producer. However, improvements in the quality of cattle herd and pasture management are also required, in order to provide conditions to improve the income of the producers.

\section{AKNOWLEDGEMENTSS}

The authors thank the partner institutions that directly or indirectly made possible the realization of this work: Embrapa (Florestas, ClimaTemperado and Pecuária Sul), Federal University of Parana, Federal University of Pelotas, Federal Agrotechnical School of Alegrete, state association of Forestry, Secretary of Agriculture of Alegrete, Emater/RS-Ascar, Maronna Foundation and Sá Brito Farm. 


\section{REFERERENCES}

Aguinaga, A. J. Q. Caracterização de sistemas de produção de bovinos de cortena região da Campanha do estado do Rio Grande do Sul.Universidade Federal doRioGrande do Sul. (Tese de Doutorado em Zootecnia), UFRGS, 2009, 150.p.

Berger R. (1979) The brazilian fiscal incentive act's influence on reflorestation activity in São Paulo State. PhD. Dissertation, Michigan State University, 80p.

Carvalho, P. C. F; Fisher, V.; Santos, D. T. dos.; Ribeiro, A. M. L.; Quadros, F. L.F. de.; Castilhos, Z. M. S.; Poli, C. H. E. C.; Monteiro, A. L. G.; Nabinger, C.; Genro, T. C. M.; Jacques, A. V. A. Produção Animal no Bioma Campos Sulinos. Brazilian Journal of Animal Science, João Pessoa, v. 35, n. Supl. Esp., p. 156-202, 2006.

Castilhos, Z.M.S., Barro R.S., Savian J.F., Amaral H.R.B. (2009) Produção arbórea e animal em sistema silvipastoril com acácia-negra (Acaciamearnsii). Pesquisa Florestal Brasileira. 60, 39-47.

Costa, L. B., Cereta, P. S., Gonçalves, M. B. F. (2006). Viabilidade econômica: análise da bovinocultura de corte. Informações Econômicas, SP, v.36, n.8, ago. 2006.

Ilha A.S., Alves F.D., Saravia L.H.B. (2006) Desigualdades regionais no Rio Grande do Sul: o caso da metade sul, in: Primeiro Encontro de Economia Gaúcha. PUCRS/FEE. Anais. Porto Alegre, 21p.

Miguel L.A., Mielitz Netto C.G.A., Nabinger C., Waquil P.D., Sanguiné E., Schneider S. (2007) Caracterização socioeconômica e produtiva da bovinocultura de corte no estado do Rio Grande do Sul. Estudo \& Debate. 14, 95-125.

Nabinger C., Ferreira E.T., Freitas A.K., Carvalho P.C.F, Sant'anna D.M. (2009) Produção animal em campo nativo: aplicações de resultados de pesquisa, in: Pillar, V.P.; Müller S.C.; Castilhos Z.M.S.; Jacques A.V.A. (Eds.). Campos sulinos: conservação e uso sustentável da biodiversidade. Brasília, pp. 175-198. florestais. Dados eletrônicos (Documentos / Embrapa Florestas, ISSN 19803958; 216). 
Oliveira E.O., Porfírio-da-Silva V., Moraes A., Ribaski J. (2006) Utilização de softwares para o manejo de plantações florestais em sistemas silvipastoris, in: Workshop sobre potencial dos sistemas silvipastoris para o desenvolvimento de modelos sustentáveis de exploração pecuária, Palestras. Juiz de Fora: Embrapa Gado de Leite, CD-ROM.

Pavan, J. A.; Alves, T. W.; Souza, M. A. de. Viabilidade Econômica da Produção de Eucaliptos no Rio Grande do Sul. ABCustos, São Leopoldo: Associação Brasileira de Custos, v. 5, n. 1, p. 92-126, jan/abr 2010

Pillar V.D., Boldrini I.I., Hasenack H., Jaques A.V.A., Both R., Müller S.C., Eggers L., Fidelis A., Santos M.M.G., Oliveira J.M., Cerveira J., Blanco C., Joner F., Cordeiro J.L.; Pinillos Galindo M. (2006) Qual o papel da pecuária na conservação dos campos, in: Pillar V.P. (Ed.) Workshop estado atual e desafios para a conservação dos campos. Porto Alegre: Universidade Federal do Rio Grande do Sul, 24p.

Rakocevic M., Ribaski J. (2003) The efficiency of Brachiariabrizantha in a silvipastoral system in Southern Brazil, in: Zlatic M., Kostadinov S., Dragovic N. (Eds.), International Conference Natural and Socio-Economic Effects of Erosion Control in Mountainous Regions, 2002, Proceedings. Belgrade: UniversityofBelgrade, FacultyofForestry, pp. 323-332.

Ribaski J. (2008) Sistemas agroflorestais: benefícios socioeconômicos e ambientais, in: Santos A.F., Novaes A.B., Santos I.F., Longuinhos M.A.A. (Eds.), II Simpósio sobre reflorestamento na região sudoeste da Bahia, 2005, Memórias, Colombo: Embrapa Florestas, Brazil, pp. 89-101.

Ribaski, J. Tecnologias silviculturais para produção de florestas energéticas [recurso eletrônico] / Jorge Ribaski. - Dados eletrônicos. - Colombo : Embrapa Florestas, 2017. 36 p. : il. color. - (Documentos / Embrapa Florestas, ISSN 19803958; 310)

Ribaski, J.; Dedecek, R. A.; Mattei, V. L.; Flores, C. A.; Vargas, A. F. C.; Ribaski, S. A. G. Sistemas silvipastoris: estratégias para o desenvolvimento rural sustentável para a metade Sul do Estado do Rio Grande do Sul. Colombo: Embrapa Florestas, 2005. 8 p.(Embrapa Florestas. Comunicado técnico, 150).

Ribeiro, J. C. C.; Verdum, R. Arenização: visão e práticas dos técnicos e gestores no sudoeste do rio grande do sul. In: VI Seminário do Programa de Pós-graduação em Geografia. A geografia da UFRGS: uma trajetória..., 2013, Porto Alegre:

UFRGS/Geociências. v. 6. p. 58-66. 
Queiroz, Universidade de São Paulo, 120p.

Ruviaro, C. F., Costa, J. S., Florindo, T. J., Rodrigues, W., Giovanna Isabelle Bom de Medeiros, G. I. B., Vasconcelos, P.S. (2016). Economic and environmental feasibility of beef production in different feed management systems in the Pampa biome, southern Brazil. Ecologicallndicators, 60, pp. 930-939.

Silva, C. F. da, Alves, T. W. Perfil da Pecuária de Corte do Rio Grande do Sul. In: III Encontro de Economia Catarinense, 2009, BLUMENAU. III Encontro de Economia Catarinense - Economia Solidária, 2009.

Silva, N. F. da. Yield and nutritional demand and eficiency of eucalypt clones in the firts and second rotations. 2013. 65 f. Dissertação (Mestrado em Fertilidade do solo e nutrição de plantas; Gênese, Morfologia e Classificação, Mineralogia, Química,) - Universidade Federal de Viçosa, Viçosa, 2013.

Stape J.L. (1997) Planejamento global e normalização de procedimentos operacionais da talhadia simples em Eucalyptus. Série Técnica IPEF, 30, 51-62.

Varella, A.C., Barro, R. S., Silva, J. L. S., Porfirio-da-Silva, V., Saibro, J. C. de. Silvopastoral Systems in the Cold Zone of Brazil. In: Pablo Luis Peria, Francis Dube, Alexandre Costa Varella. (Org.). Silvopastoral Systems in Southern South America. 1ed.New York: Springer International Publishing, 2016, v. 11, p. 231-255.

Recebido: 01 mai. 2018

Aprovado: 19 jul. 2018.

DOI: $10.3895 /$ rbpd.v7n4.8635

Como citar: RIBASKI, S. A. G.; HOEFICH, V. A.; RIBASKI J.; RIBASKI, N. G. Silvopastoral systems as a support for sustainable development in the southwestern region of the state of Rio Grande do Sul, Brazil. R. bras. Planej. Desenv.,Curitiba, v. 7, n. 4, p. 533-549, set./dez. 2018.Disponível em:

$<$ https://periodicos.utfpr.edu.br/rbpd>. Acesso em: XXX.

Correspondência:

Nayara Guetten Ribaski

R. Imac. Conceição, 1155 - Prado Velho, Curitiba - PR, Curitiba

Direito autoral: Este artigo está licenciado sob os termos da Licença CreativeCommons-Atribuição 4.0

Internacional. 